\title{
Integration of the Ukrainian Higher Education Into the Global Educational Space
}

\section{Summary}

Analysis of the modern global market features, identification of the key directions in the development of an efficient educational policy in the Ukraine and methods of accelerating the export of educational services.

Journal of Economic Literature (JEL) codes: I21, I23

Keywords: educational market, higher education, the export of educational services

\section{MAIN RESEARCH PROBLEM}

The main system characteristics of globalization include revolutions in information and communication, growth in transnational research and educational networks and relationships, integration of the world economy and the competition between nations and markets. Among these circumstances, our country must clearly identify priorities for the educational system to ensure its international competitiveness.

From an industrial society we have moved towards an economy based on knowledge. The competitiveness of the economy is determined by the volume of production or by natural resources, especially by intellectual potential, in other words, under the present conditions the main sources of knowledge and information. Knowledge becomes a source of wealth for an individual and for the state in general.

Diana Kucherenko, PhD, Associate Professor, Science and Research Institute of Social and Economic Development, Kyiv (ndi@knutd.com.ua). 
Education is one of the most important components of human development. Today the highly developed nations of the world clearly demonstrate how important the system of higher education is in the implementation of structural reforms, innovation, human freedom and improvement, wealth, growing needs, social security and so on. The globalization of the world, the rapid development in scientific research and new information technologies require accelerated development in advanced, innovative education, the creation of conditions for the advancement of personality, intelligence and spirituality. Today we can speak of a new kind globalization in the world market of higher education, with mass distribution in education seen as a guarantee of the country's competitiveness in the new global economy. Therefore, studying the trends in and consequences of globalization in the world market of educational services for the educational system of the Ukraine is important and urgent.

\section{Analysis of recent research and publications}

The challenges of globalization in the educational space are discussed by Ukrainian and foreign scientists, namely F. Altbaha, L. Verbitsky, A. Dzhurynsky, A. Lyferova, J. Knight, L. Oderiya, R. Patory, O. Sahinovoyi, P. Scott, Hans de Vita. The opportunities for the integration of the Ukrainian market of educational services are discussed in V. Zhuravsky, M. Zgurovsky and A. Andrushchenko. However, a lot of questions remain open to investigation in the field of trends in transforming education in the Ukraine to meet modern challenges of globalization of world educational market.

Isolation unsolved aspects of the problem, which the article. Integration processes in higher education intensified globalization, which was the determining factor in the development of post-industrial world.

\section{Isolation of the unsolved aspects of the problem in the article}

Integration processes in higher education have intensified globalization, which was the determining factor in the development of the post-industrial world. This is evidenced by the appearance of new information and communication technologies that serve as new forms of learning and new areas in international education:

- Increase in the number of research centres engaged in current issues of training and promoting the elaboration of appropriate proposals;

- Efforts made by developed countries at the implementation of a coherent policy, and even develop a single strategy in the field of education, including university (ECTS). However, there is an urgent need to identify the main directions of export of educational services in the Ukraine in a globalizing world educational space.

The aim of the article is to study the major trends in the global educational market and the possibility of increasing the exports of Ukrainian services in a globalized educational space. 


\section{PRESENTATION OF THE MAIN MATERIAL}

Today, the idea of "a global educational market" as a new process is manifest in the development of international relations in training. The globalization of education is uneven: currently the US is in the lead in this area, as it controls one-third of the international educational market, followed by the United Kingdom, Germany and France by 13, 10 and 9 percent, respectively. According to experts, in 2010 the educational market reached 110 billion US dollars, and the competition will continue to intensify.

The globalization of higher education fits in the process of integrating educational services as a whole, which includes transition to uniform educational programmes. The main conditions of the globalization of educational services can be identified as:

- a general trend in the globalization of the world economy;

- development in the global labour market;

- evolutionof the information society.

The modern effects of globalization, which are felt particularly acutely after the global financial crisis of 2008-2010, have clearly highlighted two groups of countries: those who benefited from globalization and the losers. The winners are the economically most developed countries and financial and industrial groups established on their basis. The category of losers include less developed countries, which have paid heavily for a shift towards an integrated global system both financially and socially. Globalization is a process that ensures the well-being of the strong to the detriment of the weak. However, the processes of globalization are inevitable for the Ukraine as well as most countries. Thus, at this stage an important task is to preserve the Ukrainian identity, culture, mentality and educational potential etc.

An important factor in the international competition for the educational market is increase in the export of education to provide additional sources of revenue for schools, as part of their images and credibility and as a necessary condition for the efficient improvement of education and science in the country. Currently, the export of educational services is implemented in the form of four basic models: students studying abroad, distance learning, opening branches and faculty exchange.

In a globalized educational market a wide range of measures need to be taken in the Ukraine to ensure the protection of the interests of national institutions and to accelerate the process of integration into the educational market by increasing the export of educational services through the following:

- Access for foreign students receiving education in universities in the Ukraine, including the facilitation of entrance exams, visas for foreign students, documentation and free access to information;

- Government support for students' studies abroad, currently increasingly funded by private philanthropists and foundations in the Ukraine. A good example to follow is the cooperation between the state and students in India, where students are exempt from the payment of tuition fees and other costs of studying abroad if they return to work in their homeland. 
- Increase in the number of licensed training places in the most prestigious educational institutions of the Ukraine;

- The use of marketing tools, including a set of measures aimed at increasing demand for education services domestic institutions;

In our opinion, the main constraints to the export of educational services and to the establishment of a competitive educational environment in the Ukraine include include the following:

1. Unstable political environment, and as a result, lower security in training;

2. The fast development of new and competitive global educational market participants. The current world market for educational services has three major competing markets:

- North American (US and Canada);

- European markets (UK, Germany and France). Today, the educational market is growing intensively, new and traditional universities are improving the quality of their services, while in many countries, particularly in the Ukraine, Russia and Europe, depopulation, declining birth rates, decrease in the ratio of young people pose major problems;

- Pacific markets (Australia, New Zealand and Japan). According to many experts, the Far Eastern region has an increasing share in the export of educational services, as their growth rates are significantly higher than that of other market participants, which allows the evolution of a fourth educational centre (China and Singapore);

3. Disparity between the quality of educational requirements in the global educational process;

4. Low-quality management in education, and as a result, high levels of obsolete logistics, which in turn reduces the quality of the teaching staff;

5. Lack of government support for the training of local students abroad and the low level of investment in the development of sciences.

6. Unsuitability and lack of preparation by national universities for teaching foreign students.

An objective assessment of the current state of the educational market in the Ukraine reveals that the key competitive advantages in the export of educational services, which may serve to attract foreign students, are the low price of tuition, the fundamental approach to teaching a subject, and the adoption of the Bologna process in the curriculum.

\section{CONGLUSIONS}

The current processes of globalization in all spheres of social life include the building of a single educational space based on the integration of national markets and educational services, and on the harmonization of educational standards. In the current context of globalization at all levels of the functioning of national economies in the world, the main trend of the global educational market - as part of the social and economic system - is integration. The Ukraine determines its place in this process to 
ensure that the education provided in the country is competitive in the European and in the global educational space, and can still have a secure and mobile labour market. An important aspect in the integration of the Ukrainian and the global educational space it should remain focused on the competitive advantages of its domestic higher education system (low cost and foreign nationals' access to higher education). At the same time, considerable work needs to be done to reduce the impact of negative factors. Therefore, the Ukraine should seriously consider the option of increasing the export of educational services, the relationship between traditional and non-traditional forms of education, and the competitiveness education.

Prospects for the use of the research results

International experience shows that the vast majority of the educational market consists of public and private sectors. The public sector reimburses educational services. In the private (non-governmental) sector educational services are sold and consumed at market prices. In this market, educational services are provided in commercial institutions or in government agencies providing services on a contractual basis. Future research could be directed at the international experience in and the internationalization features of educational activities in public and private higher education institutions, and in the mechanisms of attracting private-sector funding for universities and other educational institutions.

\section{REFERENGES}

Delanty, D.: New model of the universities. http://socio.tamp.ru/1.htm.

Leshchenko, Iryna T. (2011): Adult Education as a Phenomenon of Continuous Education. Global International Scientific Analytical Project, http://gisap.eu/ru/node/1380.

Mospan, N. (2015): Trends in the Development of Funding Mechanisms of the Higher Education Institutions in the European Union. www.narodnaosvita.kiev.ua/?page_id=2644.

OECD (2013): Foreign / international students enrolled. http://stats.oecd.org/Index.aspx?DatasetCode= RFOREIGN. 